\title{
The toxicokinetics of ketoprofen in Gyps coprotheres: toxicity due to zero-order metabolism
}

\author{
V. Naidoo $\cdot$ L. Venter $\cdot$ K. Wolter $\cdot$ M. Taggart $\cdot$ \\ R. Cuthbert
}

Received: 9 December 2009 / Accepted: 19 January 2010

(C) Springer-Verlag 2010

\begin{abstract}
In a safety study, Cape Griffon vultures (Gyps coprotheres) were dosed with ketoprofen at single doses of $\sim 1 \mathrm{mg} / \mathrm{kg}(n=5)$ and $5 \mathrm{mg} / \mathrm{kg}(n=11)$. No toxicity was reported in the $1 \mathrm{mg} / \mathrm{kg}$ group, with the $\mathrm{AUC}_{\text {inf }}, \mathrm{V}_{\mathrm{z}}$ and $\mathrm{Cl}$ being $10.42 \mu \mathrm{g} / \mathrm{ml} \mathrm{h}, 0.37 \mathrm{l} / \mathrm{kg}$ and $0.10 \mathrm{l} / \mathrm{h} \mathrm{kg}$, respectively. Toxicity occurred in the $5 \mathrm{mg} / \mathrm{kg}$ group, with 7 of the 11 birds dying. Clinical signs of toxicity included depression, loss of appetite and apparent coma. Animals died within $48 \mathrm{~h}$ of dosing. The $\mathrm{AUC}_{\mathrm{inf}}, \mathrm{V}_{\mathrm{z}}$ and $\mathrm{Cl}$ in the birds that survived were $52.26 \mu \mathrm{g} / \mathrm{ml} \mathrm{h}, 0.45 \mathrm{l} / \mathrm{kg}$ and $0.10 \mathrm{l} / \mathrm{h} \mathrm{kg}$, respectively. The $\mathrm{AUC}_{\text {inf }}, \mathrm{V}_{\mathrm{z}}$ and $\mathrm{Cl}$ in the birds those died were $207.90 \mu \mathrm{g} / \mathrm{ml} \mathrm{h}, 0.26 \mathrm{l} / \mathrm{kg}$ and $0.02 \mathrm{l} / \mathrm{h} \mathrm{kg}$, respectively. Based on the increase in the $\mathrm{AUC}_{\mathrm{inf}}$ and $\mathrm{C}_{\max }$ in the birds that died, we surmise that toxicity resulted from saturation of the metabolic process. While the exact metabolic pathway remains unknown in these vultures, we believe that toxicity may be due to pharmacogenomic differences in the cytochrome $\mathrm{P} 450$ pathway.
\end{abstract}

V. Naidoo $(\bowtie) \cdot$ L. Venter

Section of Pharmacology and Toxicology,

Department of Paraclinical Sciences,

Faculty of Veterinary Science, University of Pretoria,

Private Bag X04, Onderstepoort 0110, South Africa

e-mail: vinny.naidoo@up.ac.za

K. Wolter

The Vulture Programme of the Rhino and Lion

Non-profit Organisation, Skeerpoort, South Africa

M. Taggart

Instituto de Investigación en Recursos Cinegéticos,

Ciudad Real, Spain

R. Cuthbert

The Royal Society for the Protection of Birds,

The Lodge, Sandy, UK
Keywords Ketoprofen - Vulture conservation ·

Diclofenac · Cape Griffon vulture · NSAID

\section{Introduction}

Diclofenac (2-[2-(2,6-dicholorophenyl amino)phenyl]acetic acid) is an important non-steroidal anti-inflammatory drug (NSAID) in human medicine and is commonly used in the management of pain and inflammation associated with the joints (Burke et al. 2006). Diclofenac is a typical NSAID in that it inhibits the cyclo-oxygense (COX) enzyme system. It is slightly more selective towards the COX II enzyme than to COX I (Burke et al. 2006). Whilst this is important in reducing the incidence of side effects in humans, diclofenac is nonetheless recognised as ulcerogenic, nephrotoxic and hepatotoxic (Burke et al. 2006).

In South Asia, diclofenac is also used in veterinary medicine as an analgesic, anti-pyretic and anti-inflammatory drug in cattle (Oaks et al. 2004). Whilst the drug is probably as effective as many other available NSAIDs (such as ketoprofen, meloxicam, flunixin, carprofen), diclofenac has been very commonly used across the Asian sub-continent due to its widespread availability and cheap price (Oaks et al. 2004; Swan et al. 2006b). Unfortunately, this widespread use is now acknowledged to have led to what may be described as one of the worst environmental catastrophes in the twenty-first century: the complete devastation of resident Gyps vulture populations across the Asian subcontinent (Oaks et al. 2004). To date, the once ubiquitous Oriental white-backed vulture (Gyps bengalensis) population, which used to number tens-of-millions of birds, has declined by a staggering $99.9 \%$ in about 15 years as the result of their exposure to diclofenac residues in the cattle carcasses they commonly fed upon (Green et al. 2007; 
Prakash et al. 2007). Further, controlled toxicity studies have now shown that diclofenac is also toxic to three other Gyps vulture species (G. africanus, G. coprotheres and G. fulvus) as well as the domestic chicken (Gallus gallus), although at a higher dose for the latter (Swan et al. 2006b; Naidoo et al. 2007, 2009). At the same time, it has been clearly shown to be safe at very high doses in Turkey vultures (Cathartes aura) (Rattner et al. 2008) and in House crow (Corvus albus; unpublished work). Hence, very significant differences in toxicity between different bird species clearly exist.

Since diclofenac was identified as the major cause of Gyps declines across the Indian sub-continent in 2004, conservationists have strived to initiate effective conservation measures. Diclofenac manufacture and importation (Kumar 2006) were legally banned for veterinary purposes in the region after meloxicam was identified as a safe alternative (Swan et al. 2006a). Unfortunately, even though veterinary diclofenac is banned, other NSAIDs still pose a potential risk to vulture populations, as no data on their safety are available. In a study by Taggart et al. (2009), ketoprofen ((RS)-2-(3-benzoylphenyl) propionic acid) was found to be present in $0.5 \%$ of carcasses available to vultures within India, second only to diclofenac, meloxicam and ibuprofen (Taggart et al. 2009). Although a survey by Cuthbert et al. (2007) showed anecdotal evidence that ketoprofen had been safely used in 12 bird species ( $>22$ individual birds), its safety in vultures remained to be fully characterised (Cuthbert et al. 2007).

In an attempt to investigate the safety of ketoprofen in Gyps, we exposed adult captive non-breeding Cape Griffons (G. coprotheres) to doses of either $1 \mathrm{mg} / \mathrm{kg}$ or $5 \mathrm{mg} / \mathrm{kg}$ ( $n=5$ and 11 birds, respectively) of ketoprofen (Naidoo et al. 2010). These doses were based upon the lower and upper ranges of doses recommended for the clinical treatment of birds (Pollock et al. 2005) and were also representative of the range of doses that vultures could receive in the wild if they fed upon carcasses of livestock that had been dosed with ketoprofen in the hours before death (Naidoo et al. 2010). At $5 \mathrm{mg} / \mathrm{kg}, 7$ out of 11 birds died with typical signs previously associated with diclofenac toxicity, i.e. animals became increasingly depressed (from about $24 \mathrm{~h}$ ) until eventually becoming semi-comatose prior to death (at $\sim 40 \mathrm{~h}$ ). On necropsy, all birds also showed signs of bilateral severe nephrotoxicity and hepatotoxicity, with diffuse visceral gout. The clinical pathology was also typical of diclofenac toxicity, in that extreme increases in uric acid and plasma ALT activity were observed. As such, it was concluded that ketoprofen is toxic to Gyps vultures and should, therefore not be considered a viable safe alternative to diclofenac (Naidoo et al. 2010).

From the ketoprofen study mentioned above, in addition to monitoring the safety of ketoprofen, we also undertook regular post-treatment blood sampling in order to establish the pharmacokinetics of ketoprofen at both doses in the Cape griffon. Here, we present these results as a toxicokinetic study, and specifically focus our discussion of results on the interesting significant difference in pharmacokinetic parameters between birds that died, or survived, at the $5 \mathrm{mg} / \mathrm{kg}$ dose.

\section{Materials and methods}

Animals and dosing

Sixteen adult Cape Griffon vultures were dosed by oral gavage with ketoprofen at a $1 \mathrm{mg} / \mathrm{kg}(n=5$; Neoprofen, India) or $5 \mathrm{mg} / \mathrm{kg}$ ( $n=11$; Ketofen $10 \%$, South Africa) body weight dose, with a $1 \mathrm{ml}$ syringe (Braun). The birds were obtained from the Vulture Programme of the Rhino and Lion Non-profit Organisation. Due to the endangered status of the species, only captive non-releasable and nonbreeding birds which failed to establish captive breeding pairs were selected for the study. The birds were housed in individual cages $(2 \times 3 \times 3 \mathrm{~m})$ with hard soil floors and wooden perches. Birds had constant access to water, and were fed $1 \mathrm{~kg}$ of porcine meat twice per week. The vultures had not been fed during the $48 \mathrm{~h}$ period prior to treatment.

\section{Ketoprofen analysis}

Blood samples $(5 \mathrm{ml})$ were collected from the tarsal vein or the wing vein (when necessary), immediately before drug administration and at 5, 30 min, and at 1, 1.5, 2, 6, 8, 10 and $24 \mathrm{~h}$ after treatment. Samples were collected into $5 \mathrm{ml}$ syringes (Braun) with a $22 \mathrm{G}$ needle, then immediately transferred into heparinised or plain vacutainer tubes. Within $2 \mathrm{~h}$ of collection, these blood samples were centrifuged at $\approx 3,000 \mathrm{~g}$ for $15 \mathrm{~min}$, and the supernatant of each sample was transferred to labelled polycarbonate tubes. All samples were stored at $-20^{\circ} \mathrm{C}$ until they were transferred for analysis on dry ice to the University of Aberdeen, Scotland, UK.

Analysis of ketoprofen was undertaken using a validated LC-ESI/MS methodology (Taggart et al. 2009). Samples of plasma $(0.5 \mathrm{ml})$ were vortex mixed with $2 \mathrm{ml}$ of HPLC grade acetonitrile, then centrifuged at $\approx 1,000 \mathrm{~g}$ for $5 \mathrm{~min}$. Quantification and confirmation were undertaken at $\mathrm{m} / \mathrm{z}$ of 253.1 and 197.1, respectively, in negative ion mode following compound separation on an Agilent ZORBAX 300SB-C18 column $(4.6 \mathrm{~mm} \times 150 \mathrm{~mm}, 5 \mu \mathrm{m})$. Limits of quantification were equivalent to $12 \mu \mathrm{g} / \mathrm{kg}$ in liver tissue and plasma; and in spiked plasma (crow, Corvus sp.), recovery of ketoprofen was $94.2 \%( \pm 2.3 \%, n=3)$. 
Pharmacokinetic analysis

All curve fitting was undertaken in Kinetica 4.4.1 (Thermo Electron Corporation) using non-compartmental modelling. The elimination rate constant $(\lambda)$ and the elimination halflife $\left(\mathrm{T}_{1 / 2}\right)$ were calculated from the terminal phase. The area under the plasma concentration versus time curve (AUC) was obtained using the linear trapezoidal rule, up until the last measurable concentration $\left(\mathrm{C}_{\text {last }}\right)$, with extrapolation to infinity $\left(\mathrm{AUC}_{\mathrm{inf}}\right)$ using the elimination rate constant $\left(\mathrm{C}_{\text {last }} \mathrm{l}\right.$ $\lambda)$. Total body clearance $(\mathrm{Cl})$, volume of distribution $\left(\mathrm{V}_{\mathrm{z}}\right)$, volume of distribution at steady state $\left(\mathrm{V}_{\mathrm{ss}}\right)$ and the mean residence time (MRT) were calculated using standard formulae.

\section{Results}

As previously reported (Naidoo et al. 2010), no mortality occurred within the low dose group, while 7 of the 11 birds treated at $5 \mathrm{mg} / \mathrm{kg}$ died with the clinical signs described above. Samples were collected from all animals up to $24 \mathrm{~h}$ for the $5 \mathrm{mg} / \mathrm{kg}$ dose group. Signs of toxicity became evident at $\pm 28 \mathrm{~h}$ post-dosing which prompted the termination of the study. All 11 animals treated at $5 \mathrm{mg} / \mathrm{kg}$ were immediately taken to the Onderstepoort Veterinary Academic Hospital (OVAH) for emergency treatment. Furosemide, lactated Ringers fluid and sodium bicarbonate were administered. During treatment, animals were clinically depressed, had increased plasma potassium levels and increased uric acid accumulation. Despite treatment, all animals showed depression at the onset of therapy and then died at intervals during the subsequent $12 \mathrm{~h}$. The pharmaco- kinetic study was terminated prior to the initiation of the listed concurrent therapy.

The pharmacokinetic parameters obtained by the noncompartmental analysis are presented in Table 1, and the plasma concentration profile with time is given in Fig. 1. Ketoprofen had a $\mathrm{V}_{\mathrm{z}}$ of $\sim 0.40 \mathrm{l} / \mathrm{kg}(0.37$ and $0.45 \mathrm{l} / \mathrm{kg})$ for both the $1 \mathrm{mg}$ and $5 \mathrm{mg} / \mathrm{kg}$ (survived) groups. This was reduced for the $5 \mathrm{mg} / \mathrm{kg}$ (died) group to $\sim 0.26 \mathrm{l} / \mathrm{kg}$. A similar trend was evident in terms of clearance, where, with the 1 and $5 \mathrm{mg} / \mathrm{kg}$ (survived) groups, similar figures of approximately of 0.10 and $0.09 \mathrm{l} / \mathrm{h} \mathrm{kg}$, respectively, were recorded, but this was substantially reduced to $0.02 \mathrm{l} / \mathrm{h} \mathrm{kg}$ for the birds that died. The $\mathrm{T}_{1 / 2}$ of ketoprofen at $1 \mathrm{mg} / \mathrm{kg}$ was very rapid at $2.66 \mathrm{~h}$, and similar at $3.24 \mathrm{~h}$ for the $5 \mathrm{mg} /$ $\mathrm{kg}$ (survived) group. The half-life was markedly increased in the birds that died at $7.38 \mathrm{~h}$, i.e. being $\sim 2.5$ times longer.

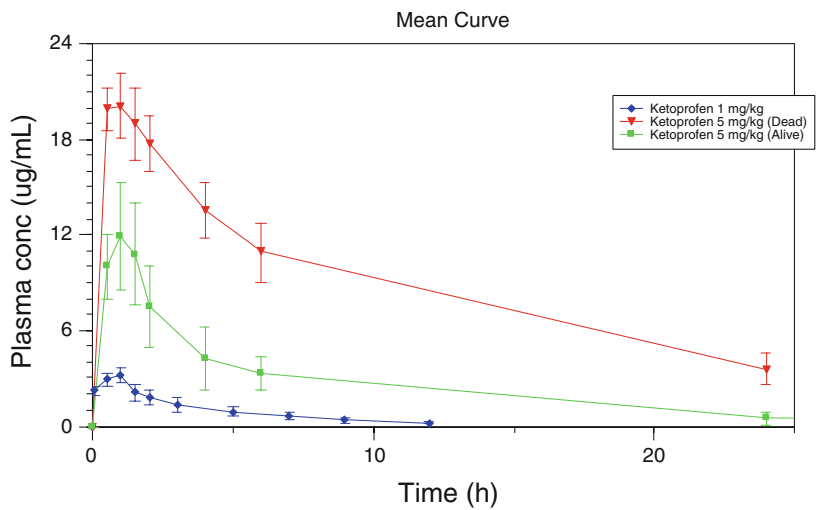

Fig. 1 Ketoprofen concentrations \pm SE in plasma versus time, for vultures treated orally at $1 \mathrm{mg} / \mathrm{mg}(n=5), 5 \mathrm{mg} / \mathrm{kg}$ (died) $(n=7$; animals that died following dosing) and $5 \mathrm{mg} / \mathrm{kg}$ (alive) $(n=4$, animals that survived dosing)

Table 1 Pharmacokinetic parameters obtained by non-compartmental modelling following the dosing of G. coprotheres with ketoprofen at two dose levels

\begin{tabular}{|c|c|c|c|c|c|c|c|c|c|}
\hline \multirow[t]{2}{*}{ Parameter } & \multicolumn{2}{|c|}{$1 \mathrm{mg} / \mathrm{kg}$ survived } & \multicolumn{3}{|c|}{$5 \mathrm{mg} / \mathrm{kg}$ survived } & \multicolumn{4}{|c|}{$5 \mathrm{mg} / \mathrm{kg}$ died } \\
\hline & GeoMean & SE & GeoMean & SE & $5: 1$ & GeoMean & SE & $5: 1$ & $5: 5$ \\
\hline $\mathrm{C}_{\max }(\mu \mathrm{g} / \mathrm{ml})$ & 3.08 & 0.45 & 10.77 & 3.26 & 3.50 & 21.00 & 1.88 & 6.83 & 1.95 \\
\hline $\mathrm{T}_{\max }(\mathrm{h})$ & 0.87 & 0.10 & 0.71 & 0.14 & 0.81 & 0.79 & 0.14 & 0.90 & 1.11 \\
\hline $\mathrm{AUC}_{\text {last }}(\mu \mathrm{g} / \mathrm{ml} \mathrm{h})$ & 9.79 & 3.23 & 50.31 & 17.71 & 5.14 & 156.51 & 33.14 & 15.99 & 3.11 \\
\hline $\mathrm{AUC}_{\text {inf }}(\mu \mathrm{g} / \mathrm{ml} \mathrm{h})$ & 10.42 & 3.70 & 52.26 & 18.36 & 5.02 & 207.90 & 49.40 & 19.96 & 3.98 \\
\hline$\lambda\left(\mathrm{h}^{-1}\right)$ & 0.26 & 0.04 & 0.21 & 0.14 & 0.82 & 0.09 & 0.03 & 0.36 & 0.44 \\
\hline $\mathrm{AUMC}_{\text {last }}\left(\mu \mathrm{g} / \mathrm{ml}(\mathrm{h})^{2}\right)$ & 28.35 & 14.40 & 224.31 & 141.43 & 7.91 & 956.18 & 396.86 & 33.73 & 4.26 \\
\hline $\mathrm{T}_{\text {half }}(\mathrm{h})$ & 2.66 & 0.46 & 3.24 & 1.59 & 1.22 & 7.38 & 1.72 & 2.78 & 2.28 \\
\hline MRT (h) & 3.49 & 0.83 & 4.97 & 2.05 & 1.43 & 10.84 & 2.44 & 3.11 & 2.18 \\
\hline $\mathrm{Cl}(\mathrm{l} / \mathrm{h} \mathrm{kg})$ & 0.10 & 0.05 & 0.10 & 0.09 & 1.00 & 0.02 & 0.01 & 0.25 & 0.25 \\
\hline $\mathrm{V}_{\mathrm{z}}(1 / \mathrm{kg})$ & 0.37 & 0.13 & 0.45 & 0.10 & 1.21 & 0.26 & 0.03 & 0.70 & 0.57 \\
\hline $\mathrm{V}_{\mathrm{ss}}(1 / \mathrm{kg})$ & 0.33 & 0.06 & 0.48 & 0.13 & 1.42 & 0.26 & 0.03 & 0.78 & 0.55 \\
\hline
\end{tabular}

The ratio represents the quotient for the two dose groups, i.e. 5:1 represents the comparison between parameters at the 5 and $1 \mathrm{mg} / \mathrm{kg}$ dose, while 5:5 represents a comparison between animals that died and animals that survived at the $5 \mathrm{mg} / \mathrm{kg}$ dose 
In terms of the rate and extent of absorption, the $\mathrm{C}_{\max }$ was threefold higher for the $5.0 \mathrm{mg} / \mathrm{kg}$ (survived) group than for the $1 \mathrm{mg} / \mathrm{kg}$ group. In contrast, in the birds that died, it was almost 7 times higher at $21.00 \mu \mathrm{g} / \mathrm{ml}$. As expected, the AUC and $\mathrm{AUC}_{\text {inf }}$ for the $5.0 \mathrm{mg} / \mathrm{kg}$ (survived) group were higher than for the $1 \mathrm{mg} / \mathrm{kg}$ group by a factor of around five. In comparison, however, for the birds that died, we noted a threefold to fourfold increase in their exposure in comparison with the birds that survived at $5 \mathrm{mg} / \mathrm{kg}$. Although the high dose group was characterised by a larger AUC, this did not translate into a longer MRT, i.e. the 1.0 and $5.0 \mathrm{mg} / \mathrm{kg}$ (survived) groups had similar MRTs. The $5 \mathrm{mg} / \mathrm{kg}$ (died) group had a substantially higher MRT, which was most likely related to the greater extent of exposure and the longer observed $\mathrm{T}_{1 / 2}$.

\section{Discussion}

While different products were used in the two stages of testing, we consider the different results and mortalities to be a consequence of dose rates, rather than due to any differences in products. The use of different formulation for the 1 and $5 \mathrm{mg} / \mathrm{kg}$ dose was unfortunately as a result of nonavailability of the Neoprofen for the second part of the study. The use of a different formulation was not considered to be too significant, as both products were in solution, and they would, therefore, be considered bioequivalent. In addition when comparing the pharmacokinetic parameters between groups given 1 and $5 \mathrm{mg} / \mathrm{kg}$ (that survived), these groups showed very similar data for all parameters, with the exception of AUC. The AUC and $\mathrm{AUC}_{\text {inf }}$ showed a fivefold increase (as the dose increased fivefold), implying that the absorption of ketoprofen in birds that lived followed the principles of linear absorption. The latter also demonstrated that the two formulations were absorbed in the same manner, as would be expected from a biopharmaceutical Class I product (Lobenberg and Amidon 2000).

The $\mathrm{T}_{1 / 2}$ of $3.24 \mathrm{~h}$ in vultures that survived at the high dose was substantially longer than the $0.5 \mathrm{~h}$ reported for Japanese Quail (Coturnix japonica), which at present is the only other avian species in which the pharmacokinetics of ketoprofen have been described to the best of our knowledge. Graham et al. (2005) also reported that the $T_{1 / 2}$ of ketoprofen in the Japanese Quail was similar to the $T_{1 / 2}$ of salicylic acid, flunixin and meloxicam reported in five other avian species. This was, however, not the case as the $T_{1 / 2}$ of ketoprofen in our study of Gyps coprotheres is sevenfold higher than that found for meloxicam in the same species (0.5 h) (Naidoo et al. 2008a). When we compare the ketoprofen $\mathrm{T}_{1 / 2}$ in birds that died with those that survived in this experiment, the $\mathrm{T}_{1 / 2}$ was $\sim 2.5$ times longer in birds that died, implicating the $T_{1 / 2}$ in toxicity. This would indicate that metabolism had perhaps reached near-zero- or zeroorder in these birds, due to saturation of the metabolic process. This best explains the resultant toxicity, and the changes in pharmacokinetic parameters seen between the birds that survived and died.

Whilst the mechanism behind ketoprofen's toxicity in $G$. coprotheres is unknown, we have previously proposed that diclofenac toxicity is related to the ability of NSAIDs to interfere with uric acid transport at the cellular level (Naidoo and Swan 2009). It is plausible that ketoprofen toxicity occurs in the same way, i.e. that the renal tubular epithelial cells become over-whelmed to such an extent that toxicity results because of oxidative damage. Most importantly, it has also been suggested that differential NSAID toxicity is related to $\mathrm{T}_{1 / 2}$ and $\mathrm{Cl}$, i.e. that diclofenac (which is highly toxic) has a longer $\mathrm{T}_{1 / 2}$, and meloxicam (which is safe) has a very short $T_{1 / 2}$.

At present, the enzymes which control the metabolism of NSAIDs in Gyps vultures are not described. However, in studies on the pharmacokinetics of meloxicam, Naidoo et al. (2008a) described the presence of a glucoronide and hydroxyl metabolite, thereby indicating that the metabolism of meloxicam at least, in Gyps vultures, is potentially similar to that found in mammals (Naidoo et al. 2008a; Lees 2009). In the recognised metabolic pathways described for mammals, the presence of the hydroxyl metabolite indicates the involvement of the cytochrome P450 (CYP450) enzyme system, whilst the glucoronide metabolite indicates the involvement of the UDP glycosyltransferase enzyme (Rodrigues 2005). At this stage, it is plausible that either of these enzymatic processes may enforce the rate limiting step in the metabolic transformation of ketoprofen. Evidence for this comes from mammalian metabolic studies in the cat and man.

From veterinary literature, the NSAIDs in particular paracetamol (acetaminophen), has been widely associated with severe toxicity in the cat (Lees 2009). Its toxicity in cats has been fully elucidated and results from deficiencies in phase II glucuronidation enzymes (Court and Greenblatt 1997; Lascelles et al. 2007). With rapid saturation of the limited feline glucoronide enzymatic system, phase I reactive metabolites accumulate within the body. It is these radicals that are then responsible for the toxic effects of paracetamol as they induce severe oxidative damage in the major organ systems. Deficiencies in the CYP450 system in Gyps may also explain the toxicity we observe for ketoprofen and diclofenac, as this would allow the accumulation of the primary drugs, which are known to induce free radical cellular damage via the inhibition of the COX pathway or via other mechanisms (Mahmud et al. 1996; Galati et al. 2002).

Of the two enzyme systems mentioned above, deficiencies in the latter (i.e. CYP450 rather than glucuronidation) is more plausible in our opinion, as significant pharmacogenomic 
differences have also been described for this system within humans (Rodrigues 2005). CYP450 pharmacogenomic differences within $G$. coprotheres (as opposed to a total deficiency in the glucoronidation pathway) would explain why only 7 of the 11 animals died following dosing at the same level $(5 \mathrm{mg} / \mathrm{kg})$. Also, it has been established in humans that the CYP2C9 enzyme is important in the clearance of ibuprofen, indomethacin, flurbiprofen, celecoxib, valdecoxib, lornoxicam, tenoxicam, meloxicamand piroxicam, whilst another (yet to be fully described) CYP450 enzyme seems to be more important in the clearance of sulindac, naproxen, ketoprofen, diclofenac, rofecoxib and etoricoxib. If we consider that meloxicam was rapidly metabolized in Gyps, but that both diclofenac and ketoprofen have comparatively longer $\mathrm{T}_{1 / 2}$ (and are both toxic), G. coprotheres are perhaps more likely to be deficient in this (yet to be fully described) enzyme system.

The increased ketoprofen $T_{1 / 2}$ in birds that died occurred alongside increases in the AUC and $\mathrm{C}_{\max }$, tends to indicate that ketoprofen undergoes a degree of presystemic elimination. While the absolute/relative bioavailability of ketoprofen has not been established for Gyps vultures, Graham et al. (2005) showed that the drug is poorly absorbed in Japanese quail, and that it had an absolute bioavailability of only $24 \%$ (Graham et al. 2005). Diclofenac has a relative bioavailability of $50 \%$ in chicken and is known to undergo presystemic elimination in $G$. coprotheres (Naidoo et al. 2007, 2009). Assuming ketoprofen and diclofenac share the same enzymatic pathways, it is plausible that ketoprofen also has a substantial first-pass effect in $G$. coprotheres If the hepatic enzyme systems are being saturated as stated above, less of the drug would undergo presystemic elimination, i.e. the extent of absorption would be increased. Since $\mathrm{C}_{\max }$ and AUC are direct indicators of the extent of absorption, the observed increases in these parameters supports the idea that in birds that died, zero-order metabolism was occurring. Similar increases in AUC and $\mathrm{C}_{\max }$ have been described for midazolam in humans, and this was reportedly linked to saturation of the presystemic elimination pathways (Bornemann et al. 1985; Thummel et al. 1996).

It is also interesting that we observed significant changes in the $\mathrm{Cl}$ of ketoprofen in birds that died (compared to those that did not). While this could simply be linked to changes in $\mathrm{T}_{1 / 2}$, other factors may have played a role. Whilst monitoring the pharmacokinetics of ketoprofen, frequent blood sampling allowed us to make a direct evaluation of renal excretion via the evaluation of uric plasma levels. In birds, uric acid is directly cleared by the kidneys; hence, changes in levels are a good indicator of renal function. Naidoo et al. (2008b) showed that uric acid levels in healthy Gyps africanus (in the absence of feeding) should remain constant in plasma. However, in birds that died, despite having not fed before treatment, increases in plasma uric acid concentrations were very evident, which could only have resulted from direct renal tubular epithelial (RTE) cell damage. Whilst RTE cell damage should not directly influence drug clearance (which requires extensive metabolism), studies in humans with renal failure have also shown a direct decrease in ketoprofen clearance (Grubb et al. 1999). The reason for the change in the clearance of ketoprofen during kidney failure is yet to be explained.

\section{Conclusion}

This study highlights that yet another NSAID (beyond diclofenac) is inherently toxic towards Gyps vultures, and perhaps a wider range of avian species. Ketoprofen can no longer be considered safe towards Gyps, and as such cannot (and should not) be used as an alternative within veterinary medicine on the Indian sub-continent to replace diclofenac. The use of ketoprofen as a veterinary NSAID for treating livestock in Southern Africa and Europe also raises concerns over the potential impact of this drug on vulture populations within these regions. Meloxicam now remains the "only" safe alternative available which is accepted as therapeutically effective and safe towards a wide range of avian scavengers. At the same time, this study also highlights the continuing need to test a wider range of available NSAIDs on a wide range of avian scavengers, with Gyps vultures being a particular priority.

Acknowledgments Ethics approval was obtained from the Animal Use and Care Committee of the University of Pretoria. The study was also approved by Gauteng Nature Conservation (GDACE) in accordance with the National Biodiversity Act.

\section{References}

Bornemann LD, Min BH, Crews T, Rees MC, Blumenthal HP, Colburn W, Patel IH (1985) Dose dependant pharmacokinetics of midazolam. Eur J Clin Pharmacol 29:91-95

Burke A, Smyth E, FitzGerald GA (2006) Analgesic-antipyretic agents; pharmacotherapy of gout. In: Brunton LL, Lazo JS, Parker KL (eds) Goodman and Gilman's the pharmacological basis of therapeutics, 11th edn. McGraw-Hill Companies, USA, pp 671-715

Court MH, Greenblatt DJ (1997) Molecular basis for deficient acetoaminophen glucuronidation in cats. Biochem Pharmacol 53:10411047

Cuthbert R, Parry-Jones J, Green RE, Pain DJ (2007) NSAIDs and scavenging birds: potential impacts beyond Asia's critically endangered vultures. Biol Lett 3:90-93

Galati G, Tafazoli S, Sabzevari O, Chan TS, O’Brien PJ (2002) Idiosyncratic NSAID drug induced oxidative stress. Chem Biol Interact 142:25-41

Graham JE, Kollias-Baker C, Craigmill AL, Thomasy SM, Tell LA (2005) Pharmacokinetics of ketoprofen in Japanese quail (Coturnix japonica). J Vet Pharmacol Ther 28(4):399-402

Green RE, Taggart MA, Senacha KR, Raghavan B, Pain DJ, Jhala Y, Cuthbert R (2007) Rate of decline of the oriental white-backed 
vulture population in India estimated from a survey of diclofenac residues in carcasses of ungulates. PLoS ONE 2:e686

Grubb NG, Rudy DW, Brater DC, Hall SD (1999) Stereoselective pharmacokinetics of ketoprofen and ketoprofen glucoronide in end-stage renal disease; evidence for a 'futile cycle' of elimination. Br J Clin Pharmacol 48:494-500

Kumar A (2006) Diclofenac for veterinary use. Letter to all state drug controllers from the drug controller general (India) F.No. 18-03/ 2006-DC

Lascelles DX, Court MH, Hardie EM, Robertson SA (2007) Nonsteroidal anti-inflammatory drugs in cats: a review. Vet Anaesth Analg 34:228-250

Lees P (2009) Analgesics, antiinflammatory, antipyretic drugs. In: Riviere JE, Papich MG (eds) Veterinary pharmacology and therapeutics, 9th edn. Wiley, USA, pp 457-492

Lobenberg R, Amidon GL (2000) Modern bioavailability, bioequivalence and biopharmaceutics classification system. New scientific approaches to international regulatory standards. Eur J Pharm Biopharm 50:3-12

Mahmud T, Scott DL, Bjarnason I (1996) A unifying hypothesis for the mechanism of NSAID related gastrointestinal toxicity. Ann Rheum Dis 55:211-213

Naidoo V, Swan GE (2009) Diclofenac toxicity in Gyps vulture is associated with decreased uric acid excretion and not renal portal vasoconstriction. Comp Biochem Physiol C Comp Pharmacol Toxicol 149:269-274

Naidoo V, Duncan N, Bekker L, Swan G (2007) Validating the domestic fowl as a model to investigate the pathophysiology of diclofenac in Gyps vultures. Environ Toxicol Pharmacol 24:260-266

Naidoo V, Wolter K, Cromarty AD, Bartels P, Bekker L, McGaw L, Taggart MA, Cuthbert R, Swan GE (2008a) The pharmacokinetics of meloxicam in vultures. J Vet Pharmacol Ther 31:128-234

Naidoo V, Diekmann M, Wolters K, Swan GE (2008b) Establishment of selected baseline blood chemistry and hematologic parameters in captive and wild-caught African white-backed vultures (Gyps africanus). J Wildl Dis 44:649-654

Naidoo V, Wolter K, Cuthbert R, Duncan N (2009) Veterinary diclofenac threatens Africa's endangered vulture species. Regul Toxicol Pharmacol 53:205-208
Naidoo V, Wolter K, Cromarty D, Diekmann M, Duncan N, Meharg AA, Taggart MA, Venter L, Cuthbert R (2010) Toxicity of nonsteroidal anti-inflammatory drugs to Gyps vultures: a new threat from ketoprofen. Biol Lett. doi:10.1098/rsbl.2009.0818

Oaks JL, Gilbert M, Virani MZ, Watson RT, Meteyer CU, Rideout BA, Shivaprasad HL, Ahmed S, Chaudhry MJ, Arshad M, Mahmood S, Ali A, Khan AA (2004) Diclofenac residues as the cause of vulture population decline in Pakistan. Nature 427:630-633

Pollock C, Carpenter JW, Antinoff N (2005) Nonsteroidal antiinflammatory drugs used in birds. In: Carpenter JW (ed) Exotic animal formulary, 3rd edn. Elsevier Saunders, St. Louise, pp 220-222

Prakash V, Green RE, Pain DJ, Ranade SP, Saravanan S, Prakash N, Venkitachalam R, Cuthbert R, Rahmani AR, Cunningham AA (2007) Recent changes in populations of resident Gyps vultures in India. J Bombay Nat Hist Soc 104:129-135

Rattner BA, Whitehead MA, Gasper G, Meteyer CU, Link WA, Taggart MA, Meharg AA, Pattee OH, Pain DJ (2008) Apparent tolerance of Turkey vultures (Cathartes aura) to the non-steroidal anti-inflammatory drug diclofenac. Environ Toxicol Chem 27:2341-2345

Rodrigues AD (2005) Impact of CYP2C9 genotype on pharmacokinetics: are all cyclooxygenase inhibitors the same? Drug Metab Dispos 33:1567-1575

Swan G, Naidoo V, Cuthbert R, Green RE, Pain DJ, Swarup D, Prakash V, Taggart M, Bekker L, Das D, Diekmann J, Diekmann M, Killian E, Meharg A, Patra RC, Saini M, Wolter K (2006a) Removing the threat of diclofenac to critically endangered Asian vultures. Plos Biol 4:e66

Swan GE, Cuthbert R, Quevedo M, Green RE, Pain DJ, Bartels P, Cunningham AA, Duncan N, Meharg AA, Oaks JL, Parry-Jones J, Shultz S, Taggart MA, Verdoorn G, Wolter K (2006b) Toxicity of diclofenac to Gyps vultures. Biol Lett 2:279-282

Taggart M, Senacha KR, Green RE, Cuthbert R, Jhala YV, Meharg AA, Mateo R, Pain DJ (2009) Analysis of nine NSAIDs in ungulate tissues available to critically endangered vultures in India. Environ Sci Technol 43:4561-4566

Thummel KE, O'Shea D, Paine MF, Shen DD, Kunze KL, Perkins JD, Wilkinson GR (1996) Oral first-pass elimination of midazolam involves both gastrointestinal and hepatic CYP3A-mediated metabolism. Clin Pharmacol Ther 59:491-502 